\title{
OPTIMIZATION OF IRRIGATION WATER FLOWING SCHEDULING SYSTEM USING GENETIC ALGORITHM METHOD WITH SPATIAL GEOGRAPHICAL APPROACHES: A CASE STUDY OF KEULILING DAM IN ACEH BESAR DISTRICT, INDONESIA
}

\author{
Nuratuzzakiah*, Rusdiana Siti, Gani Taufiq A., Zahnur \\ Postgraduate Program, University of Syiah Kuala, Indonesia \\ ${ }^{\star}$ E-mail: Nuratu zakiah@yahoo.co.id
}

\begin{abstract}
Keuliling Reservoir which is located in Kuta Cot Glie, Aceh Besar is one of the reservoirs that have a function as a provider of water for irrigation needs, supports food self-sufficiency programs and others. The reservoir area has limited volume of water so, the most important water-saving irrigation water should be done to determine the scheduling of the distribution of irrigation water to the area of rice fields. The purpose of this research is to develop a method that can be used to the calculation of scheduling and can be applied to the irrigation of the Keuliling Reservoir watershed in Aceh Besar. In this study, the Genetic Algorithm method was used to determine the optimization of the Keuliling Reservoir in the Aceh Besar. From the analysis that has been done, by test of the Genetic Algorithm method, the minimum optimization of the time and discharge of irrigation water is obtained. While the visualization of these results can be displayed using the Matlab GUI software. The remaining disposal of irrigation water into the Keumireu watershed at one hour of irrigation has the minimum value of 600 Liters / Hour. The best irrigation time obtained is based on the calculation of 72 Genetic Algorithm methods in which the amount of water entering the rice field area is $1,038,211,600$ Liters and 257,788,400 Wasted in the river. Based on the results of testing the application of the Keuliling Reservoir watershed irrigation scheduling in Aceh Besar that was built with Genetic Algorithms can solve optimal scheduling problems.
\end{abstract}

\section{KEY WORDS}

Irrigation, scheduling, genetic algorithms, optimization.

The potential of water resources in Indonesia is very abundant at around 3,200 billion $\mathrm{m}^{3} /$ year in 7956 rivers and 521 lakes. The availability of water around 700 billion m3/year makes Indonesia one of the wettest countries in the world (Hasan 2012). The availability of water in a watershed is influenced by climatic, topographic, geological, vegetation and hydrological processes (Niagara et al. 2016). Utilization of water resources is increasing along with the rate of population growth and various sectors of activities that are increasingly developing. In addition to household needs, water availability is also needed for the needs of rice irrigation and industrial irrigation. According to the Director General of Natural Resources (2011) reported that raw water that has been used for households and urban areas has reached $3.7 \%$ of the total amount of water that has been utilized, the rest is used for irrigation of $80.5 \%$ and industrial activities of $15.8 \%$. Irrigation water requirements for wetland rice require different volumes of water for each growth phase (Subagyono et al. 2001). The need for wetland water for one planting season is $1744 \mathrm{~mm}$ or $1.6 \mathrm{l} / \mathrm{sec} /$ ha during the rainy season, while in the dry season is $1940 \mathrm{~mm}$ or $1.8 \mathrm{l} / \mathrm{sec} / \mathrm{ha}$, so the average per planting season is 1.7 $\mathrm{l} / \mathrm{sec} /$ ha (Notohadiprawiro 2006). Aceh Province, especially Aceh Besar District uses an irrigation system to drain agricultural land, especially in villages in the Keuliling Dam area. The existence of irrigation is expected to increase land production through increasing cropping intensity and increasing land productivity.

The limited flow of water in the dry season often affects agricultural production and land productivity. To overcome this problem, irrigation scheduling efforts at the Keuliling Dam will be the right solution. Scheduling can be done using the Genetic Algorithm Method. The Genetic Algorithm method is expected to provide the optimal solution to the optimization problems [Admi Syarif. 2014]. The method of Genetic Algorithm is now being applied to 
irrigation scheduling problems to optimize water volume. Therefore, the distribution of water from the Keuliling Dam in Aceh Besar District is expected to be available optimally using the method of Genetic Algorithms and the Spatial Geographical approach. This study aimed to optimize the distribution of irrigation water by scheduling the Keuliling Dam by using the Genetic Algorithm method.

\section{METHODS OF RESEARCH}

This research was conducted at the Computing Laboratory for Mathematics Modeling and Simulation in Syiah Kuala University. This research lasts for six months, from August 2018 until January 2019.

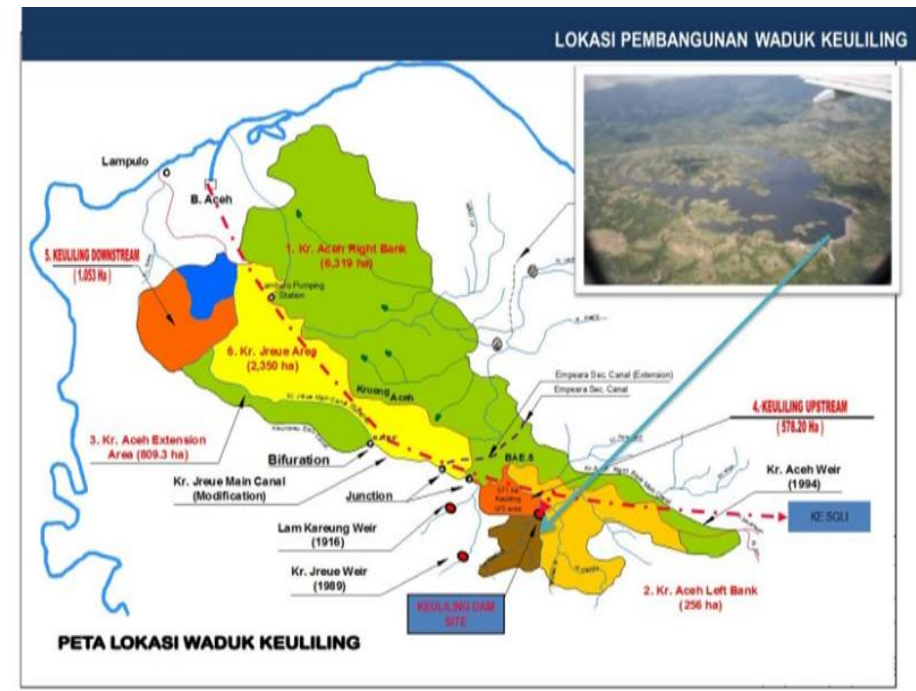

Figure 1 - Study Location

This research requires basic data, namely water flow data. While the technical data related to this problem uses land area data and irrigation time data.

Table 1 - Keuliling Dam Floodgate Data

\begin{tabular}{ccccc}
\hline No & Name of Floodgate & Water Flow of Floodgate (Liter/second) & Land Area (Ha) & Time (t) \\
\hline 1 & BKL 1 & 10.440 .000 & 1710 & 36 \\
2 & BKL 2 & 9.943 .200 & 1624 & 36 \\
3 & BKL 3 & 2.822 .400 & 490 & 35 \\
4 & BKL 4 & 266.400 & 50,9 & 24 \\
5 & BKL 5 & 270.000 & 50 & 22 \\
6 & BKL 6 & 298.800 & 30,25 & 20 \\
7 & BKL 7 & 120.000 & 15 & 15 \\
8 & BKL 8 & 3.750 .000 & 500 & 35 \\
9 & BBS 1 & 565.700 & 85,75 & 24 \\
10 & B.Pa. 1 & 350.000 & 28,05 & 15 \\
11 & BBS 2 & 375.000 & 70,80 & 30 \\
12 & BSH 1 & 482.400 & 81,25 & 33 \\
13 & BSH 2 & 105.000 & 13,5 & 12 \\
14 & BSH 3 & 250.600 & 41 & 28 \\
\hline
\end{tabular}

Source: Office of Public Works and Spatial Planning of Aceh Besar District.

The optimization technique used the Genetic Algorithm Method, and the spatial approach was simulated using the Matlab GUI application. The linear program assumed that all variables and decision-making parameters were linearly related. The formulation of the mathematical model developed by Chairil F, 2005 led to the optimization of irrigation water which enter farmland. While the researchers developed the formulation by optimizing the 
scheduling of irrigation water flow in the irrigation floodgate of the Keuliling Dam against time (t), so that the wasted water becomes minimal by considering the following assumptions:

- The condition of all irrigation channels at each floodgate when water flows;

- The value of the water flow at each floodgate is constant ( $\mathrm{dj}=$ Constant);

- $t=$ Time for irrigation;

- $\quad D=$ The water flow constant is $18,000,000$ Liters/Hour.

$$
j=\left\{\begin{array}{l}
1 \text { Opened Floogate condition } \\
0 \text { Closed Floodgate condition }
\end{array}\right.
$$

Minimizing the volume of water flow distribution in the irrigation system at the flood gate facility to minimize wasted water.

$$
\operatorname{Min} V=\sum_{t=1}^{T} G_{t}
$$

Where: $V=$ Water Volume; $G_{t}=$ The remaining irrigation water which wasted into the river with time, where $t \in\{1,2,3, \ldots, T\} ; T=$ Period of irrigation water flow in the Keuliling Dam of the Aceh Besar District to the floodgates.

The constraint function is divided into water availability constraints and time constraints, with formula:

Constraints for flow of irrigation water that enters rice fields at time t.

$$
P_{t}=\sum_{t=1}^{T} X_{t, j} \cdot d_{j} \leq D
$$

Where: $V=$ Volume of Keuliling Dam; $\mathrm{D}=$ Constant of water flow; intake/dam of 18.000.000; Liter/hours; $\mathrm{t}=$ Irrigation scheduling time; $\mathrm{j}=$ Irrigation floodgate; $d_{j}=$ water flow of $\mathrm{j}$-th floodgate; $X_{t, j}=$ Schedule for irrigation water at $\mathrm{t}$-time of $\mathrm{j}$-th floodgate.

Constraints of irrigation water flow that is wasted into the river at t-time.

$$
G_{t}=D-\sum_{t=1}^{T} P_{t}
$$

\section{RESULTS AND DISCUSSION}

Keuliling Dam Watershed Profile. Keuliling Dam is one of the sub-watersheds of the Keumireu River which has a potential area of $4,790.5$ ha. The dam holds \pm 18 million $\mathrm{m}^{3}$ with an inundation area of $228 \mathrm{Ha}$ and a catchment area of $38.20 \mathrm{Km}^{2}$. The Keuliling Dam meets the water requirements for the Krueng Aceh Extension and Krueng Jreue irrigation area of $3,159.30 \mathrm{Ha}$. Technical data related to this problem are data of land area and times of irrigation [Sumatra River Regional Office, 2017]. When the Keuliling Dam Profile button is pressed in the main view of the system, the system will display the Keuliling Dam Watershed Profile form by having one intake gate and 14 secondary canals as shown in Figure 2.

The search for the location of irrigation water gate facilities was carried out using Global Positioning System (GPS) equipment. Field coordinates got by using the Google Earth Pro application. Searching results were determined by the position of each floodgate which flows through the rice fields. The coordinates of the location of the floodgate object passed by the Keuliling Dam watershed in Aceh Besar Regency are found in Table 2. 
PROFIL DAS WADUK KEULILING KABUPATEN ACEH BESAR
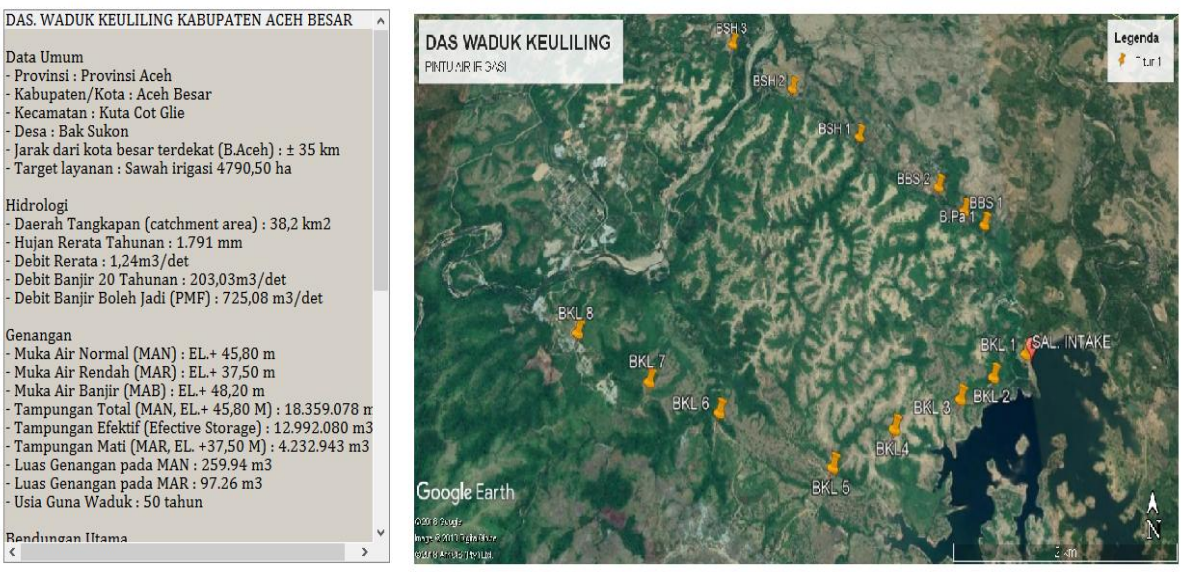

MENU

Figure 2 - Keuliling Dam Watershed Profile

Table 2 - Coordinate of Irrigation Floodgate on Keuliling Dam Watershed in Aceh Besar District

\begin{tabular}{ccccc}
\hline \multirow{2}{*}{ No } & Point & Name of Floodgate & \multicolumn{2}{c}{ Coordinates } \\
\cline { 4 - 5 } & $P_{1}$ & BKL 1 & 5,215055 & Longitude \\
\hline 2 & $P_{2}$ & BKL 2 & 5,214439 & 95,282618 \\
3 & $P_{3}$ & BKL 3 & 5,213859 & 95,281486 \\
4 & $P_{4}$ & BKL 4 & 5,213119 & 95,283510 \\
5 & $P_{5}$ & BKL 5 & 5,212228 & 95,274238 \\
6 & $P_{6}$ & BKL 6 & 5,213527 & 95,272322 \\
7 & $P_{7}$ & BKL 7 & 5,214238 & 95,264829 \\
8 & $P_{8}$ & BKL 8 & 5,215586 & 95,262612 \\
9 & $P_{9}$ & B.Pa 1 & 5,222789 & 95,261150 \\
10 & $P_{10}$ & BBS 1 & 5,223226 & 95,281808 \\
11 & $P_{11}$ & BBS 2 & 5,224006 & 95,281159 \\
12 & $P_{12}$ & BSH 1 & 5,225727 & 95,283300 \\
13 & $P_{13}$ & BSH 2 & 5,231474 & 95,273568 \\
14 & $P_{14}$ & BSH 3 & 5,233241 & 95,271077 \\
& & & & 95,264703 \\
\hline
\end{tabular}

The results of the search for coordinates in the table above can be proven by searching in the field. Searching for coordinates using the Google Earth Pro application can be seen in Figure 3.

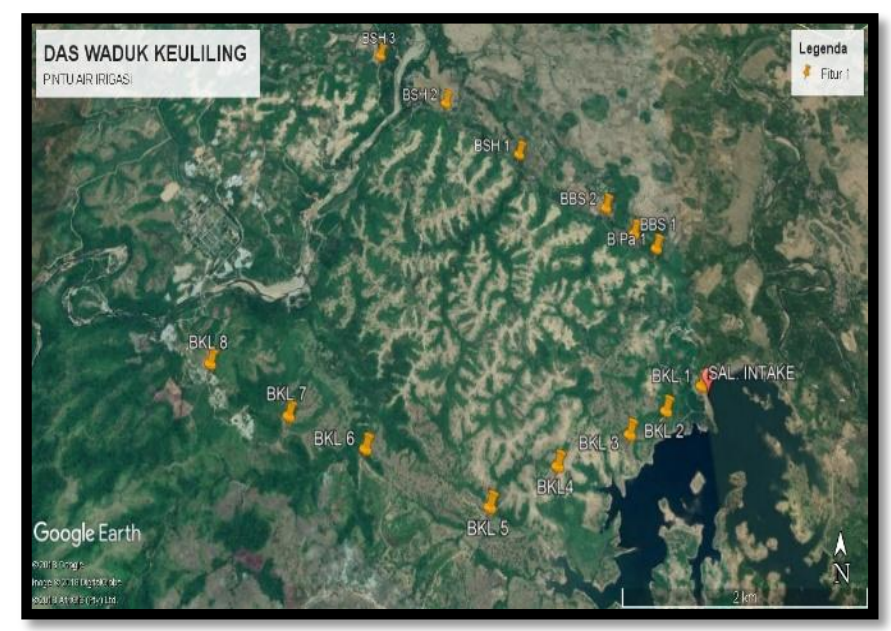

Figure 3 - Coordinates using the Google Earth Pro 
Chromosome Initialization. Chromosomes for scheduling problems can be illustrated by using a coded string, symbolized by the string length of 14 , which is called a chromosome. A total of 50 populations mean that there are around 50 solutions for 72 hours of scheduling irrigation water in the Keuliling Dam watershed in Aceh Besar District. Each chromosome contains binary values between 1 and 0 , where 1 then the irrigation floodgate is open, while 0 irrigation floodgates is closed. Determination of chromosome initialization focuses on multiplication between time and value of water flow at irrigation flood gate must be smaller with intake, where flow at intake gate (D) is constant that is equal to $18,000,000$ Liters/Hour.

$$
P_{t}=\sum_{t=1}^{T} X_{t, j} \cdot d_{j} \leq D
$$

First solution for $\mathrm{t}=1$ :

$\left.P_{t}=\sum_{t=1}^{T} 10.440 .000+0+2.822 .400+0+0+0+0+3.750 .000+565.700+0+375.000+0+0+0\right)=17.935 .100 \leq D \leq \mathrm{D}$

Fitness Function. The fitness function focuses on its objective function. In this system, the fitness function minimizes the volume of irrigation water in the dam where:

$$
\mathrm{f}=\frac{1}{\log \mathrm{G}_{\mathrm{t}}}, \text { dimana } \mathrm{G}_{\mathrm{t}}=\mathrm{D}-\mathrm{P}_{\mathrm{t}}
$$

Where: $\mathrm{f}=$ Fitness function; $\mathrm{G}_{\mathrm{t}}=$ Difference between dam waterflow and irrigation waterflow at each floodgate; $\mathrm{D}=$ Irrigation waterflow at the intake gate of the dam; $\mathrm{P}_{\mathrm{t}}=$ Irrigation water flow at $t$-th the floodgates.

Table 3 - Fitness Function

\begin{tabular}{cccc}
\hline $\mathrm{t}$ & $\begin{array}{c}P_{t} \\
(\text { Liter/hour })\end{array}$ & $\begin{array}{c}G_{t} \\
(\text { Liter/hour })\end{array}$ & $\frac{1}{\log G_{t}}$ \\
\hline 1 & 17.953 .100 & 46.900 & 0,214079 \\
2 & 14.936 .100 & 3.063 .900 & 0,154172 \\
3 & 15.223 .300 & 2.776 .700 & 0,155194 \\
4 & 5.522 .600 & 12.477 .400 & 0,140922 \\
5 & 11.966 .400 & 6.033 .600 & 0,14748 \\
$:$ & $:$ & $:$ & 0,140748 \\
72 & 5.267 .600 & 12.732 .400 & 0 \\
\hline
\end{tabular}

Fitness Probability. The cumulative value of the fitness probability obtained was 1 , this can be seen based on the definition of probability theory, the probability value ranges between 0 - 1 intervals where, that is, the probability value produced should not be more than 1. The maximum probability value produced must be 1 .

Roulette Wheel Selection Method. At this stage, chromosomes are selected according to their fitness value. The first step that can be performed is the fitness value that has been obtained and carried out an addition. Then random numbers are generated. Sequential fitness values can be compared to random numbers that have been generated. If $\frac{\text { value Fitness }}{\text { Total Fitness }}>$ fitness value/total fitness $>$ random numbers that have been generated, then the chromosome will be selected as the main for the next process.

Crossover and Mutation. The crossover method used is the one cut point crossover method. This method is carried out by selecting two parents which crossover to determine the cut point. One time the crossover process produces one child. The child from the crossover will have the first chromosome from the parent along the cut point, and get the remaining chromosomes from the second parent. Cut point is used in research along 7 genes and is worth 0 and 1 . The process of mutation can occur with several special possibilities for each gene from a chromosome called random only improving. The floodgates from time and large floodgates are chosen randomly and exchanged if they have a better 
solution. The mutation process will be directed according to the condition of the flow of irrigation water in the Keuliling Dam watershed in Aceh Besar District. The mutation process will be adjusted to the size of the water flow and the time needed to drain the water at each irrigation water gate facility. If the water flow process is in long time, it will be prioritized so that the water flow in the dam can be optimized. Then the mutation is performed by exchanging 0 bit to 1 , and 1 bit to 0 .

Literation of Generation. After all stages have been completed, it can be concluded that the time for scheduling the Keuliling dam watershed irrigation in Aceh Besar Regency which starts from $t=1$ until the end of the supply of water to the rice fields when $t=72$. While the most optimal value for scheduling at certain hours with the remaining water wasted very little, which is 600 Liters / Hour. The open gate schedule is BKL 1, BKL 3, BKL 4, BKL 7, BKL 8, B.Pa.1, and BSH 3. The overall results of water during the scheduling which supply to each irrigation floodgate was 1,296,000,000 liters. The number of water that enters into the rice fields was $1,038,211,600$ liters and the amount of wasted irrigation water was $257,788,400$ liters. The search results for the optimal solution from the scheduling of Keuliling Dam watershed irrigation in Aceh Besar District by using Genetic Algorithms produce scheduling with a minimum amount of time. The amount of time needed to irrigate $4,790.50$ ha of rice fields through secondary irrigation of 14 gates is 72 hours. While the total amount of irrigation water that enters the rice fields is $1,038,211,600$ Liters, and which wasted into the river is $257,788,400$ Liters. Thus, the use of the Genetic Algorithm method can be used as an option in solving optimization problems in scheduling system problems.

\section{CONCLUSION}

In terms of irrigation time and irrigation water flow the application of the Genetic Algorithm method for scheduling watershed irrigation water can be produced optimally. The condition of wasted irrigation water into the river is minimized and water entering the rice fields can be maximized through a scheduling system.

The calculation results of optimizing in the scheduling of Keuliling Dam watershed irrigation in Aceh Besar Regency byvusing the Genetic Algorithm method resulted in the total amount of irrigation water entering the rice fields of 1,038,211,600 Liters. The total irrigation water wasted into the river was $257,788,400$ Liters and for 72 Hours irrigation water flows to rice fields.

\section{REFERENCES}

1. Admi Syarif, Dr.Eng. 2014. Algoritma Genetika: Teori and Aplikasi Edisi 2. Penerbit Graha Ilmu, Yogyakarta, Indonesia.

2. Balai Wilayah Sungai Sumatera I., 2017. Profil Balai Wilayah Sungai Sumatera I. Direktorat Jendral Sumber Daya Air Departemen Pekerjaan Umum and Penataan Ruang. Banda Aceh.

3. Hasan M. 2012. Ketahanan air and pangan. Media informasi sumber daya air. Seksi komunikasi publik sub direktorrat data and informasi direktorat bina program sumber daya air Kementerian Pekerjaan Umum. Edisi Mei-Juni Tahun 2012.

4. Niagara R, Purwanto Y, Suharnoto Y. 2016. Analisis debit air and airtanah dangkal daerah aliran sungai (DAS) Prumpung, Kabupaten Tuban. J Pengelolaan Sumberdaya Alam and Lingkungan. 6(1):20-30. doi:10.19081/jpsl.6.1.2.

5. Notohadiprawiro T. 2006. Rasionalisasi Penggunaan Sumberdaya Air dillndonesia. Yogyakarta (ID): Universitas Gajah Mada.

6. Subagyono K. 2004. Tanah Sawah and Teknologi Pengelolaannya. Bogor (ID): Pusat Penelitian and Pengembangan Tanah and Agroklimat. 